\title{
Physical Expressions of Winning Hearts and Minds: Body Politics of the American Missionaries in "Asiatic Turkey"
}

\author{
Nazan Maksudyan
}

This paper discusses the use of visual representations or photographic descriptions by the missionaries of the American Board of Commissioners for Foreign Missions (ABCFM) as proofs of their proselytizing efforts. The analysis is limited to the American missionaries of the "Asiatic Turkey Mission", namely Western Turkey Mission (established in 1819), Central Turkey Mission (1847) and Eastern Turkey Mission (1836), whose proselytizing efforts centralized its work mainly on Armenians. ${ }^{1}$ I argue that bodily conditions of targeted constituencies and their physical surroundings (rooms, houses, villages) were reconceived and re-conceptualized by American missionaries as material representations and mirrors of religious and moral progress. This was usually done in the genre of before-and-after photographs or detailed physical descriptions, one criticizing or pitying the former "wretchedness" of people, and the other appraising how they "grew finer". Assuming that sincere belief, or for that matter conversion, is a delicate matter to present evidence for, these visual representations or descriptions were useful tools to convince the world of believers and benevolent contributors that these people were genuinely "civilized" into good Christians and were leading a Christian life.

The ABCFM, founded in 1810, established its first missions in the Ottoman Empire in 1819 and became by the second half of 19th century quite influential in the Anatolian provinces of the Empire, especially in socio-cultural fields of relief, education, and health. ${ }^{2}$ The specificities of their experience

1 For more information on the work of АВСFM missionaries among the Armenians, see Barbara J. Merguerian, "'Missions in Eden': Shaping an Educational and Social Program for the Armenians in Eastern Turkey (1855-1895)," in New Faith in Ancient Lands: Western Missions in the Middle East in the Nineteenth and Early Twentieth Centuries, ed. Heleen Murre-van den Berg. sсм 32 (Leiden: Brill, 2006), 241-262.

2 There were substantive regional differences in target populations, experiences and strategies of American missionaries stationed in different parts of the Ottoman Empire, namely the Balkans, Anatolia, Arab provinces. Compared to their relatively safe and well-established stand in most of the Anatolian provinces, the American missionaries did not necessarily gain 
in the Ottoman lands-successive failure among the Muslims and then the Jews, and later never-ending controversies with Orthodox communities, both Armenians and Greeks - made the ABCFM alter their approach from a narrow effort to "save souls" into a broad program of "cultivate minds". ${ }^{3}$ The ABCFM missionaries realized early on that the communities would not easily receive a missionary simply as a preacher of the gospel, but they would accept a school (a teacher) or an infirmary (a doctor) quite willingly. Thanks to their educational, medical, and humanitarian services, the АВCFM missionaries served as a second layer of communal support-in addition to the one that the communities formally belonged. They successfully used these institutions to have access to other religious denominations, since they admitted everyone in their schools and hospitals, not necessarily to convert them, but "make an impression" upon them as to "what true Christianity is". Elshakry argued that even though American missionaries "failed in their mission to save souls - their success in terms of numbers of actual converts to the Protestant Church was never very impressive - they were nevertheless said to have helped win the battle for the 'conversion to modernities'4 in the Middle East". 5 That is why, Protestantism as represented by the ABCFM became a main ideological enemy in the eyes of the Sultan, since it was considered as one of the major factors in the renaissance of Armenian and Syriac self-consciousness, especially because of their emphasis on the use of vernacular languages. ${ }^{6}$

As the main material of this essay, I concentrate on an interesting section of the Missionary Herald, one of the mostly circulating Board publications:

much local respect in the province of Syria. See for instance, Habib Badr, "American Protestant Missionary Beginnings in Beirut and Istanbul: Policy, Politics, Practice and Response," in New Faith in Ancient Lands: Western Missions in the Middle East in the Nineteenth and Early Twentieth Centuries, ed. Heleen Murre-van den Berg (Leiden: Brill, 2006): 211-240; Ussama Makdisi, The Culture of Sectarianism: Community, History, and Violence in Nineteenth-Century Ottoman Lebanon (Berkeley: University of California Press, 200o).

3 Barbara J. Merguerian, "Saving Souls or Cultivating Minds? Missionary Crosby H. Wheeler in Kharpert, Turkey," Journal of the Society for Armenian Studies 6 (1992-1993): 33-6o; Ellen Fleischmann, "Evangelization or Education: American Protestant Missionaries, the American Board, and the Girls and Women of Syria (1830-1910)," in New Faith in Ancient Lands. Western Missions in the Middle East in the Nineteenth and Early Twentieth Centuries, ed. Heleen Murrevan den Berg (Leiden: Brill, 2006), 263-280.

4 Peter van der Veer, ed., Conversion to Modernities: The Globalization of Christianity (New York: Routledge, 1996).

5 Marwa Elshakry, "The Gospel of Science and American Evangelism in Late Ottoman Beirut," Past and Present 196, no. 1 (2007): 173-214.

6 Hans-Lukas Kieser, "Mission as Factor of Change in Turkey (Nineteenth to First Half of Twentieth Century)," Islam and Christian-Muslim Relations 13 (2002): 391-410. 
"For Young People". Starting from 1879, each monthly issue included a brief illustrated article designed for "young people". This designation is in itself interesting, since it is not certain if the target audience was essentially children. If we assume that it was so, the age group must have shaped the narratives and focus of the stories and photos. This might explain less precision and more generalization (in an Orientalistic fashion) in describing different religions, ethnic groups, and manners and customs. Yet, the young readers understandably were not expected to support the ABCFM financially, but they were prepared for future support. Moreover, since "For Young People" was a part within the Missionary Herald, the section editors were mainly appealing to the preferences and worldviews of their principal readers, the parents. After all, it was them who would financially support the AвCFM. Thus, the target group of the section was children as much as the adults.

Shortly after its appearance, it was concluded that "Young People" department met a real demand and that these articles were widely read. Many of them were copied into other magazines and religious papers in the United States and in Great Britain. Moreover, they were compiled in two books, one in 1885 and the other in 1897, as a collection under the name of Mission Stories in Many Lands: A Bookfor Young People. ${ }^{7}$ They were purchased for Sunday School libraries and also used by Mission Circles and Young People's Societies of Christian Endeavor. With their illustrations and touching stories, they became one of the Board's main PR outlets to advertise their success at proselytizing and collect more donations.

Accounts of people and scenes in lands far away, and of the heroic men and women who have labored with zeal and success for the good of men of other climes and tongues, are among the best sources of instruction and stimulus for readers young or old. ${ }^{8}$

Many of these stories focused on the misery of people and life in general in "Asiatic Turkey". The first group of articles focused on and told stories of those who were genuinely physically deprived and in real destitution, such as lepers, the orphaned, starved, and sick. As a second strategy, they interpreted the bodies, surroundings, and dwellings of regular (not sick or destitute) people also within this general picture of misery. In other words, healthy people's bodies,

7 Mission Stories of Many Lands: A Book for Young People (Boston: The ABCFM, 1885); In Lands Afar: A Second Series of Mission Stories of Many Lands, A Book for Young People (Boston: ABCFM, 1897).

8 In Lands Afar, iv. 
dress, cleanliness, grooming was pathologized, together with their dwellings, villages, and even interpersonal relations. These were presented as deformed, degrading, undignified, and heathen and the АВСFM missionaries defined their role as fixing these through conversion to Protestantism. Protestant missionary indoctrination through sermons, everyday interaction, school education and medical care was to reform people and places, both materially and spiritually, into "good-looking and Christian" entities. Therefore, the changes in human bodies and people's living conditions were presented as representations of internalization of Christian teachings. Those who received some form of Protestant influence were miraculously leaving their old habits behind and were reborn as new men and women. It is in fact telling that the American missionaries positioned themselves as quasi-physicians: they were there to heal not only real diseases and deprivations, but also the social and spiritual ills.

A third group of articles was purportedly anthropological/sociological pieces on various ethnic/religious groups in the Empire, such as Kurds, Armenians, Greeks, Yezidees, Albanians, and so on. These are purely Orientalist descriptions of their traditional costumes, cuisine, and "national character". ${ }^{9}$ Photographs accompanying the articles acted in a precise way to establish specific stereotypes and markers of inferiority, both of the people and of their homelands. Photographs also expressed distinctions between "Oriental peoples" and missionaries from an ambivalent point of view: As agents of "a superior culture", they most often envisioned their subjects as objects of both inferiority and fascination..$^{10}$

Visual Representations of Conversion: Before-and-After Photographs

As soon as photography was introduced to the Ottoman Empire by the midnineteenth century, ${ }^{11}$ missionaries started to use it as a way to authenticate

$9 \quad$ In their study of postcards, Malek Alloula and David Proschaska show how photography evinced Orientalist discourse. Malek Alloula, The Colonial Harem (Minneapolis, Minn.: University of Minnesota, 1986); David Prochaska, "Archive of l' Algerie Imaginaire," History and Anthropology 4 (1990): 373-420.

10 Eleanor M. Hight and Gary D. Sampson, eds., Colonialist Photography: Imag(in)ing Race and Place (London: Routledge, 2004), 1.

11 The first known photograph is of Rais al-Tin Palace, in Alexandria, taken on November 7 , 1839. For more information, see Jacob M. Landau, Exploring Ottoman and Turkish History (London: Hurst \& Co., 2004), 101-104; Engin Çizgen, Photography in the Ottoman Empire (Istanbul: Haşet Kitabevi, 1987); Wolf-Deiter Lemke, "Ottoman Photography: Recording 
their experiences in distant parts of the world and to establish "a visual impression of 'heathenism' more dramatic than could be achieved with the written word". ${ }^{12}$ Next to tourists, painters, artists, art historians and journalists, missionaries were a large group of photographers in the Empire. They found it useful to illustrate their tracts with photographs, and so from early on the mission stations tried to acquire the necessary equipment and know-how to take and print photographs. ${ }^{13}$ By the late 19th century, photography became an established part of different forms of field work, including Christian ministry.

The discourse of before-and-after was always omnipresent in АВCFM publications. It conveyed an image of accomplishment on the part of the missionaries and a promise of remarkable alteration on the part of the targets. Therefore, the relationship between conversion and visual representation was a strong one, in which photographs operated as complex discursive objects of power and culture. ${ }^{14}$ As eyewitness evidence of Ottoman reality, photographs played a significant part in reproducing the stereotype that Ottomans were degenerates in need of guidance from the Protestants. ${ }^{15}$ The pictures of those whose physical features in terms of dress, cleanliness, or posture were dramatically inferior, potentially hostile, or disruptive were used in the "before narrative" in order to justify the value of Protestant missions.

As proofs of reclamation of freedom for the "long-enslaved Eastern Churches", of "spiritual conquest of the people", mainly of evangelization, they relied on showing how despicable pre-missionary life was and how it wonderfully improved with the intervention of the Protestants. Formulaic conversion anecdotes published alongside a pair of photographs (often one taken before and other after supposed conversion) within the reports and articles that appeared in the Missionary Herald served as proofs of achievement in the field, which was necessary to legitimate the continuing flow of funds. They reinforced the difference of the "other" and therefore the need for missions as

and Contributing to Modernity," in The Empire in the City: Arab Provincial Capitals in the Late Ottoman Empire, eds. Jens Hanssen, Thomas Philipp, and Stefan Weber (Beirut: Ergon Verlag Würzburg, 2002), 237-249.

12 Barbara Lawson, "Collecting Cultures: Canadian Missionaries, Pacific Islanders, and Museums," in Canadian Missionaries, Indigenous Peoples: Representing Religion at Home and Abroad, eds. Alvyn Austin and Jamie S. Scott (Toronto: University of Toronto Press, 2005), 256 .

13 Landau, Exploring Ottoman and Turkish History, 103.

14 Hight, Colonialist Photography, 1.

15 Ayshe Erdogdu, "Picturing Alterity: Representational Strategies in Victorian Type Photographs of Ottoman Men," in Colonialist Photography: Imag(in)ing Race and Place, eds. Eleanor M. Hight and Gary D. Sampson (London: Routledge, 2004), 122. 
assimilating and evangelizing forces. In that sense, the American missionaries depended on the ability of the photographs to convey "a sense of mission to the viewer who responded with increased prayer and increased giving." 16

All the articles in the "For Young People" were published along with visual material, such as photographs, engravings and drawings. When there was no visual to display certain people and places, the American missionaries relied on their literary skills and provided very detailed, even photographic descriptions. The visual qualities of the articles mirrored the missionaries' understanding of the propagandistic power of photographs when placed alongside personal testimony. They were used as tools to tangibly confirm that evangelical activity had yielded widespread cultural and spiritual transformation. American missionaries' reports largely relied on transformation of the bodies and physical surroundings of the people of "Asiatic Turkey". In that sense, changes in the living conditions and customs of the people, "social progress" as it was presented, was the main indicator of conversion.

The missionaries used photography as if it can also capture people's beliefs. In their quest to give visibility to "true Christianity", they had to devise solid, material proofs of inner belief that one can see. Therefore, ironically, true faith, which the Protestants praised without concession, was actually reduced into a set of material, observable traits. Although social change was presented as the spillover effect of proselytizing, in fact it was the essence of conversion itself. People were, in effect, converted into a certain definition of "civilization" (with its tangible definitions of cleanliness, neatness, nutrition, hygiene, home, domesticity, family life, order, child-rearing, and so on) rather than into an abstract set of rules (religion).

"Growing Fine": Armenian Orphans and the АвсFM

The American missionaries' "visual success" was crystallized in the description and depiction of the orphans in their orphanages. These children were in a most extreme destitution before arrival and were under absolute missionary control thereafter. The ABCFM had always embraced philanthropy as a part of its missionary mandate. The missionary work was divided into four departments. Next to evangelistic work, publication, and education, philanthropy was an important part of the missions. ${ }^{17}$ The missionaries organized

16 Carol Williams, Framing the West: Race, Gender, and the Photographic Frontier in the Pacific Northwest (Oxford: Oxford University Press, 2003), 88.

17 Rev. George F. Herrick, "Canon Taylor on Missionary Methods," Missionary Herald vol. 85 (January 1889): 13-16. 
local relief measures in the case of fires, earthquakes, famines, and diseases. Relief for the orphans had one outstanding advantage, given manifold religious and social limitations of the American missionary establishments: they were free from family ties, which made conversion to Protestantism very difficult or even impossible. ${ }^{18}$

The opening of the ABCFM orphanages within the "Asiatic Turkey" mission started after the Armenian massacres of $1894-1896,{ }^{19}$ which orphaned around $5^{0}$,ooo children. ${ }^{20}$ Before that, the missions only had three very small-scale asylums. But these events forced the missionaries to open more than sixty orphanages in around thirty districts. The number of orphans in each orphanage ranged from $5^{\circ}$ to 1,000 , though they had in average about 100 children. The orphan asylums of the ABCFM were thought to have provided for around 10,00o orphans in the following decade after the massacres. These massacres made the missionaries content with their operations, as they had found a great opportunity to make a massive impact on the local population. ${ }^{21}$

Before-and-after narrative was strong in American missionary writings about orphans and orphanages. Long depictions of children's bodily features were provided, describing in detail how they were received in miserable conditions of dirt, sores, and vermin and how they were tamed in the hands of the missionaries into clean, good-looking, and well-behaved children. Orphan girls, coming "literally in rags", without "shoes or anything warm for winter", were furnished with "plain but neat cotton or woolen dresses". ${ }^{22}$ They were now "clean,

18 Roland Löffler, "The Metamorphosis of a Pietistic Missionary and Educational Institution into a Social Services Enterprise: The Case of the Syrian Orphanage (186o-1945)," in New Faith in Ancient Lands: Western Missions in the Middle East in the Nineteenth and Early Twentieth Centuries, ed. Heleen Murre-van den Berg. SCM 32 (Leiden: Brill, 20o6), 157.

19 For further information on the Eastern Anatolian Armenian massacres in the late 189os and the involvement of the American Protestant missionaries in the relief efforts, see Hans-Lukas Kieser, Der verpasste Friede: Mission, Ethnie und Staat in den Ostprovinzen der Türkei 1839-1938 (Zurich: Chronos Verlag, 2000); Selim Deringil, “'The Armenian Question is Finally Closed': Mass Conversions of Armenians in Anatolia during the Hamidian Massacres of 1895-1897," Comparative Studies in Society and History $5^{1}$ (2009): 344-371; Margaret Lavinia Anderson, “'Down in Turkey, Far Away': Human Rights, the Armenian Massacres, and Orientalism in Wilhelmine Germany," The Journal of Modern History 79 (2007): 80-111.

20 It was generally argued by the contemporaries that there were around 50 ,ooo destitute orphans. "Editorial Paragraphs," Missionary Herald vol. 95 (October 1899): 396; "Fifty Thousand Orphans made so by the Turkish Massacres of Armenians," New York Times, December 18,1896 .

21 Nazan Maksudyan, "'Being Saved to Serve': Armenian Orphans of 1894-96 and Interested Relief in Missionary Orphanages," Turcica 42 (2010): 47-88.

22 Miss Nason, “Work for Orphans," Missionary Herald vol. 93 (March 1897): 112-113. 
merciful, obedient, rapidly learning both in books and in Christian life, so different from the wretched little creatures they were when they first came in". ${ }^{23}$

The ABCFM missionaries tried to change behaviors and social attitudes of the orphans by implementing Protestant work ethics. Among their main pedagogical aims were cleanliness, passion and continuity at work, teamwork, and mutual responsibility. ${ }^{24}$ The American missionaries argued that the orphans they had sheltered, clothed, cared for, and disciplined were regarded with admiration by the whole community around them, as their physical conditions improved after they were institutionalized. An anecdote from Urfa exemplifies the perception.

As these boys were taking a walk on a recent day a group of people stopped to gaze at them, and one said, 'Does Miss Shattuck pick out all the fine boys in the community for her orphanage?' 'No' replied another, 'they grow fine after she has had them a little while'. ${ }^{25}$

As dirty, half-starved and neglected orphans, they were "other children", based on otherness of need, poverty, and undesirability. The missionary relief thus made them both "children" and believers. Orphanages were a useful tool to convince the world of believers and benevolent contributors of the progress realized with these "other children". Thus, children were not only physically cleaned and cared for, but they were transformed into "sleek, bright and interesting" children and true members of the Protestant community.

We could wish the city claimed a photographer as then we could enclose a couple of contested pictures of some of these 'wards of Christendom' as they appeared upon reaching the Home-dirty, ragged, emaciated, covered with sores and vermin - and as they appear now—clean, comfortably clothed, sleek, bright and interesting. The transformation is wonderful. ${ }^{26}$

Missionaries were so convinced of the power that photography exerted upon their supporters and contributors that Dr Gates of Harput even wrote that if he were able to send pictures "of these wretched, wan little waifs he would not

23 "Merzifon Station Report, 1897," ABC 16.9.3, reel 6o6, nos. 698-67o.

24 Löffler, "The Metamorphosis of a Pietistic Missionary," 161.

25 "Editorial Paragraphs," Missionary Herald vol. 93 (June 1897): 216. (Italics mine).

26 "Mardin Orphanage, Reports for 1897-1899," ABC 16.5, reel 512, nos. 201-230. The quote was taken from to "Report of Mardin Orphan Department for 1897." 


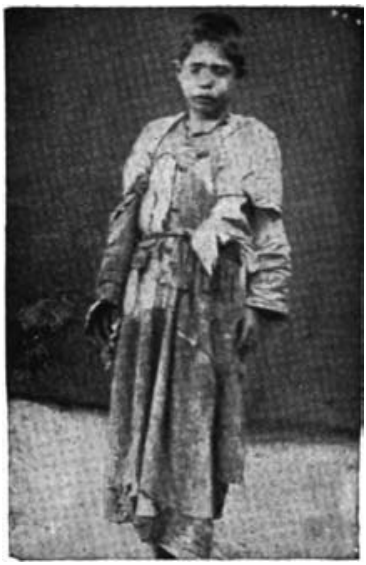

FIGURE 3.1

Aram (before photograph). Reproduced from "For Young People: Orphans in Turkey," Missionary Herald vol. 94 (May 1898): 204-208

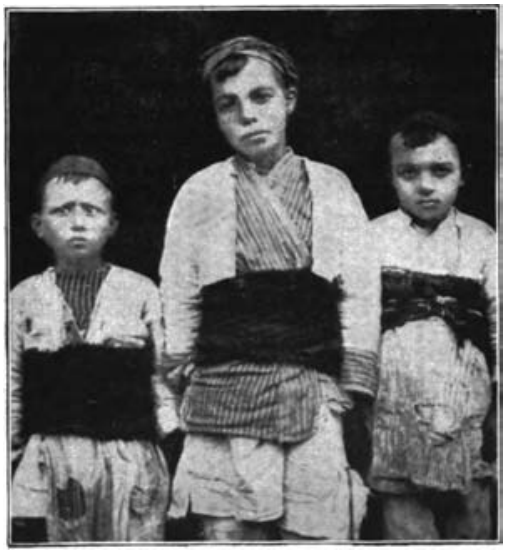

FIGURE 3.2

Boys coming to Home (before photograph). Reproduced from "For Young People: Orphans in Turkey," Missionary Herald vol. 94 (May 1898): 204-208

need to write anything". ${ }^{27}$ Actually, the article contains a photo-engraving of an orphan, Aram as he is called, taken just as he came to the orphanage at Harput. However, in reality "this boy was not as destitute and wretched as many of the children were when they first came" (Figure 3.1). ${ }^{28}$

Another photograph of three little boys, also "taken just as when they came", is also not so impressing (Figure 3.2).

In other words, these "before" pictures were not as heartbreaking and shocking as Dr Gates wanted it to be. Just as in the case of lamenting for not finding a photographer to document the before-and-after conditions of children,

27 "For Young People: Orphans in Turkey," Missionary Herald vol. 94 (May 1898): 204-208.

28 Ibid., 204. 


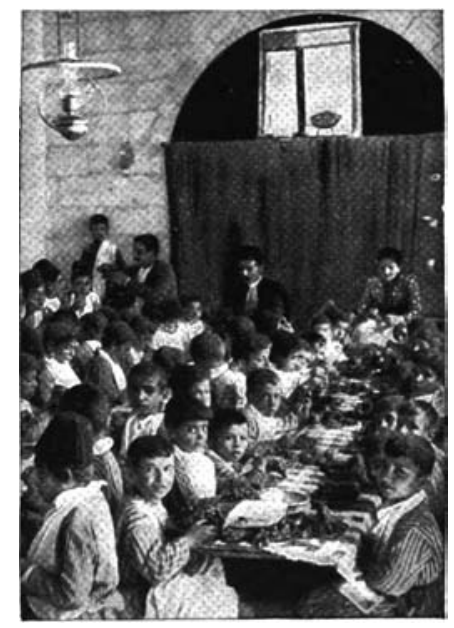

FIGURE 3.3

Orphans at Oorfa at dinner (after photograph). Reproduced from "For Young People: Orphans in Turkey,"

Missionary Herald vol. 94 (May 1898): 204-208

the missionaries regretted the fact that the photograph could not capture the extent of misery they wanted to present to the world. Still the sense of contrast created with "after" pictures was thought to compensate for it.

But it does not take a great while to change their whole appearance. They are washed and clean but coarse clothing is given to them, and they are fed on simple food, which seems to them like the greatest of luxuries. The contrast between Aram and some of the pictures which follow will indicate in some degree what this orphanage work has done for the children. ${ }^{29}$

In a picture, boys from the orphanage at Urfa were shown at dinnertime. They were neatly dressed, well-prepared within the dining hall, with a smile on their faces. This time the missionary described both the kind of food they were about to have and the religious content of their upbringing in the orphanage by referring to the blessing they prayed for just before starting to eat (Figure 3.3).

The boys are sitting on the floor matting, each one having a tin plate filled with grapes. Cucumbers and bread are arranged in little piles on the table. The house father and house mother are seated at the farther end of the table and the boys are looking up, just after the blessing has been asked. ${ }^{30}$

29 Ibid.

$30 \quad$ Ibid., 206. 


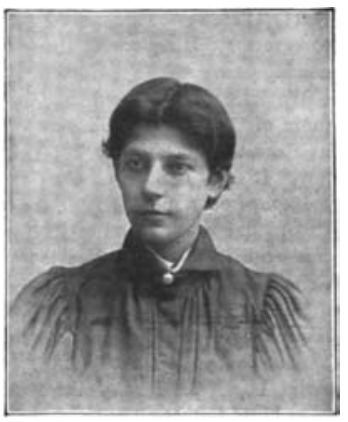

FIGURE 3.4

A rescued orphan girl (after photograph). Reproduced from "For Young People: Orphans in Turkey," Missionary Herald vol. 94 (May 1898): 204-208

In another story about the Armenian orphans under the care of American missionaries, again two photographs were used and the reader was warned to "look on this picture and then on that" in order to comprehend "what changes are wrought by this work for orphans". ${ }^{31}$ The "medicine" that brought about the complete transformation was apparently nothing but the religious instruction that they were providing (Figure 3.4).

It is not a patent medicine that we are advertising ... All four of these children are Armenian orphans ... of November 30, 1895. The boys were photographed just as they came to us. [Figure 3.2] The girl was photographed after a year spent in the pleasant parsonage in Germany to which she was sent after her terrible experience. The medicine that wrought the change was simply a practical application of the Master's words, 'Ye ought also to love one another'.32

According to ABCFM's interpretation, the Armenians were the most appropriate targets of conversion activity. Even among the Armenians, missionaries had difficulty entering into communities. Crisis periods, when the community was in need of humanitarian assistance, were beneficial for the missionaries. The misery of the people could always be turned into an "opportunity". The Armenian massacres of 1894-1896 created a similar atmosphere of hopefulness and heightened visions for conversion. As I have discussed elsewhere, the missionaries in the field were more than content, as they had finally found a great opportunity to make a massive impact on the local population. ${ }^{33}$ The Armenian

31 Ibid., 207-208.

32 Ibid., 207-208.

33 Maksudyan, "'Being Saved to Serve'” 
orphans were often defined as invaluable targets, since the missionaries hoped that "many of the orphans" would "give themselves to Christ" and would "love a Christian life". 34

\section{3}

\section{A Christian Body, a Christian Home}

The American missionaries assumed that inner religious beliefs were perceptible through material state of bodies. Styles of dress, manners, physical decorum, and cleanliness were taken to be outward signs of evangelical piety and virtue. Therefore, embracing Western-style clothing and hairdressing, postures, and rules of hygiene were coupled with conversion to Protestant faith. Transition from false to true Christianity required a process of bodily refashioning, imposed by missionaries' own standards of clothing, appearances, conduct, sanitation, and hygiene. ${ }^{35}$ In their efforts to tame and correct bodies, the American missionaries, first of all, underlined the importance of cleanliness and personal hygiene and worked hard to foster "cleanliness as a social virtue" in many places where they established missions. Converts were claimed to become "more prepossessing and more tidy in person and environment", to such an extent that they were visibly recognizable by their state of hygiene.

Missions have done much to teach personal cleanliness and household hygiene. The homes of all girls educated in mission schools are conspicuous for their betterment in this regard. Protestant families are models to all in the matter of neatness and freedom from slovenly habits. ${ }^{36}$

The ABCFM missionaries frequently argued that "dirt is domesticated in the homes of the people" and "disgusting slovenliness - in many instances intolerable filth-is more or less characteristic of the individual". ${ }^{37}$ Therefore, as an initial target American missionaries attempted to "baptize the villages and

34 George E. White, "Annual Report of Merzifon Station 1905-1906," salt Archives, American Board of Commissioners for Foreign Missions, ABAASRooo313, https://archives.saltresear ch.org/handle/123456789/46791.

35 For photography's role in the representation of the body and forms of social discipline, see Suren Lalvani, Photography, Vision, and the Production of Modern Bodies (Albany, N.Y.: State University of New York Press, 1996).

36 Rev. James S. Dennis, Christian Missions and Social Progress: A Sociological Study of Foreign Missions (New York: Fleming H. Revell Company, 1899), 459 (Report of Dr Geoger E. Pist of Beirut). (Italics mine).

Dennis, Christian Missions, 458. 
homes". They were extremely critical of many aspects of local domestic life, from sleeping and living in the same room to eating from a common pot. They claimed that "neither in the Turkish or Armenian language is there any word for home", and that all that there is, is "a house or dwelling-place."38 Houses and physical surroundings were among the first targets of evangelization; and this meant teaching and imposing their own standards of "home" on the natives. Based on their physical and material expectation of a home, the missionaries worked for the inculcation of a new sense and concept of home, together with new home ethics and home economics. ${ }^{39}$

American missionaries described the social life of the Ottomans as "one of great degradation". 40 As people's dwellings usually consisted of just one room, the missionaries argued that they were "living and eating and sleeping like domesticated animals". ${ }^{41}$ In a consistent and repeated manner, houses were compared to stables and people to animals. Within this discourse, "the whole family herded" in an "often filthy and unwholesome" room. ${ }^{42}$ In a similar fashion, many families were "content to occupy the same winter quarters as their cattle, in dark, unventilated stables". ${ }^{43}$

The most compelling duty of the Christian missions was to teach the basics of sanitation and cleanliness. It was declared with pride that with the establishment of the mission stations, the living conditions of the locals were dramatically transformed and uplifted "from that of the beasts to that of men", "from barbarity to the level of civility". New minds "aroused by the Gospel", were not simply building additional rooms in their houses, but they were in fact starting to appreciate "the fact that man is higher than the animal, and so worthy of a better place in which to live." 44 Projecting the language and jargon of proselytizing onto physical surroundings and places, АBCFM missionary reports underlined that "great and blessed changes" were apparent in thousands of homes thanks to the direct influence of mission work. ${ }^{45}$

38 "For Young People: The Empire of the Sultan," Missionary Herald vol. 77 (January 1881): 35.

39 Ellen Fleischmann, "Lost in Translation: Home Economics and the Sidon Girls' School of Lebanon, c. 1924-1932," Social Sciences and Mission 23 (2010): 32-62.

40 "Influence of American Missionaries on the Social Life of the East," Missionary Herald vol. 69 (June 1873): 187-19o.

41 Ibid.

42 Dennis, Christian Missions, 262. (From the report of Charles C. Tracy, missionary of Marsovan).

43 Dennis, Christian Missions, 459. (From the report of Rev. Dr J.L. Barton, missionary from Istanbul).

44 Ibid.

45 Dennis, Christian Missions, 265. (From the report of Charles C. Tracy of Marsovan): "It is safe to say that as the result of Christian missions great and blessed changes are apparent in thousands of homes." 


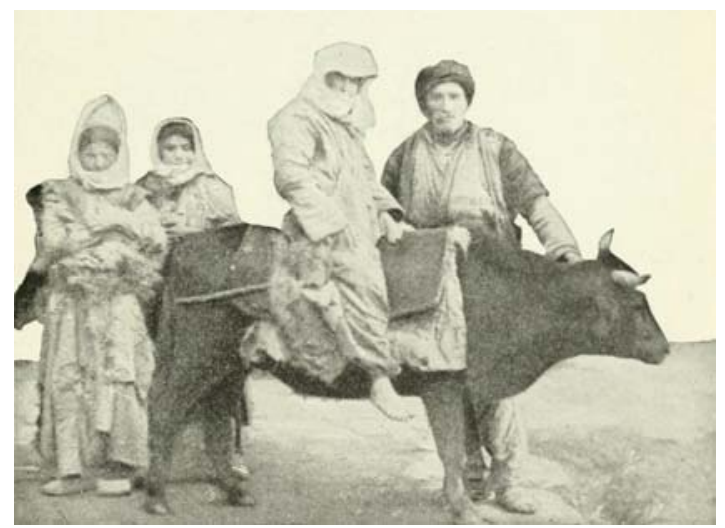

FIGURE 3.5 Village Armenians (before photograph).

Reproduced from Rev. George C. Reynolds, "For Young People: A Gospel Triumph in the Land of Ararat," Missionary Herald vol. 91 (May 1895): 212-216

It is a very conspicuous fact that where the Gospel has gained an entrance into a house or village, 'home' means much more than it did. There is a more intelligent outlook upon the world at large. The whole appearance of the house and family shows more cleanliness and neatness. ${ }^{46}$

Newly proselytized people and communities "immediately evince[d] a desire to change the sanitary conditions of their homes as well as their villages". ${ }^{47}$ It was reported that much greater "regard to the laws of health" in the arrangement of homes and in "attention to cleanliness of the person and of the household" was apparent. ${ }^{48}$ As a visual testimony of a "Gospel Triumph in the Land of Ararat", villagers from the Van region were photographed before and after adherence to the evangelical faith. The first picture depicted "the coarse and scanty clothing, the stolid faces, the use of the ox as a beast of burden (...) a few copper and earthen vessels in which to cook and eat their food, and some coarse carpets under which they might sleep at night on the ground" (Figure 3.5$) \cdot{ }^{49}$

46 Dennis, Christian Missions, 266. (From the report of Rev. John A. Ainslie of Mosul).

47 Dennis, Christian Missions, 459 .

48 Dennis, Christian Missions, 459. (Report of Dr G.C. Raynolds of Van).

49 Rev. George C. Reynolds, "For Young People: A Gospel Triumph in the Land of Ararat," Missionary Herald vol. 91 (May 1895): 212-216. 


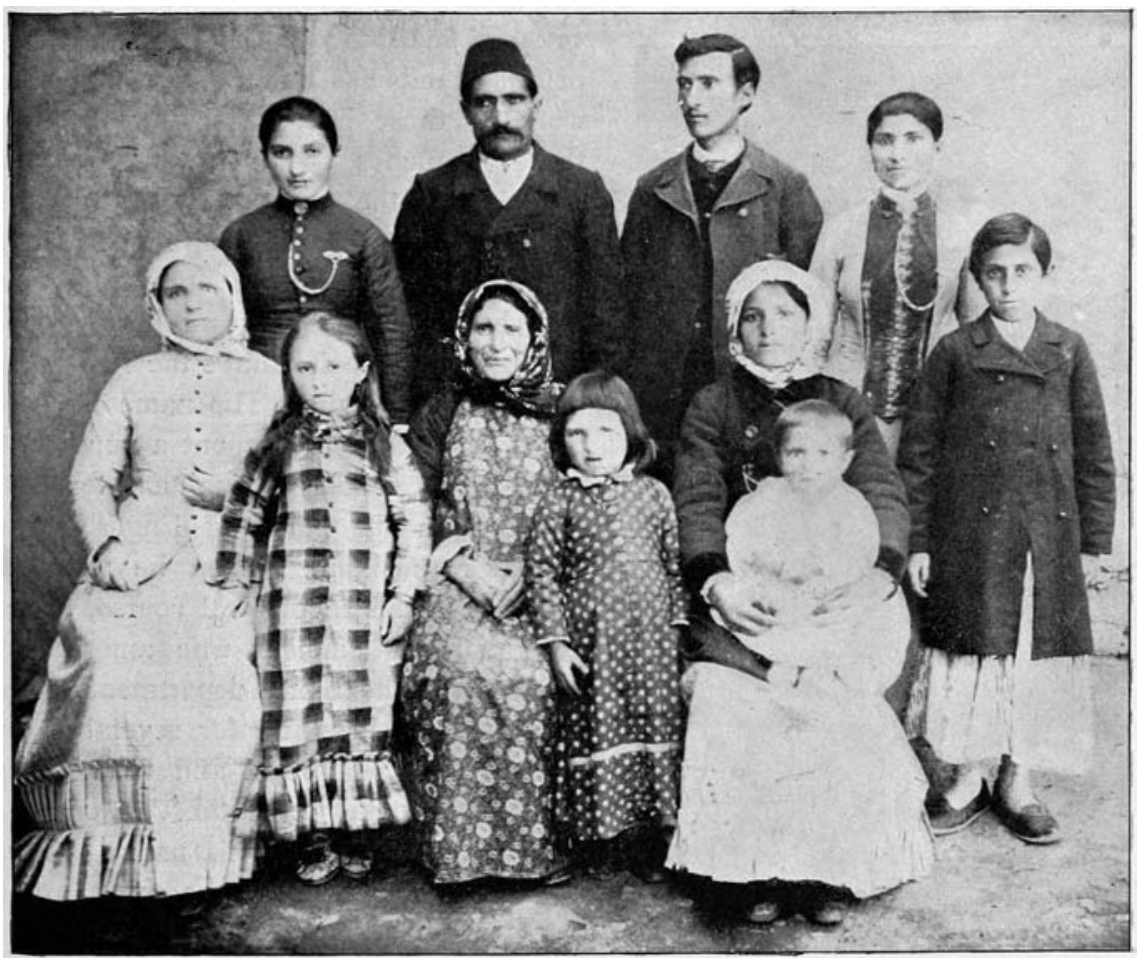

FIGURE 3.6 The family at Van (after photograph). Reproduced from Rev. George C. Reynolds, "For Young People: A Gospel Triumph in the Land of Ararat," Missionary Herald vol. 91 (May 1895): 212-216

The photo taken after twelve years of missionary work portrayed the "transforming gospel influences" on family life and "bear[ed] witness to missionary achievement" (Figure 3.6).50

The students in missionary schools and colleges were frequently used as examples of "best practices". They were following the new rules that they had been taught and were very important as transmitters of this knowledge and as pioneers and models for their communities. J.E. Pierce of Bardezag was sorry that he did not have the "before picture" of his students in the Armenian boys' school, but he was also confident that their "after photograph" would impress the readers of "For Young People". He also noted in a group photo of 


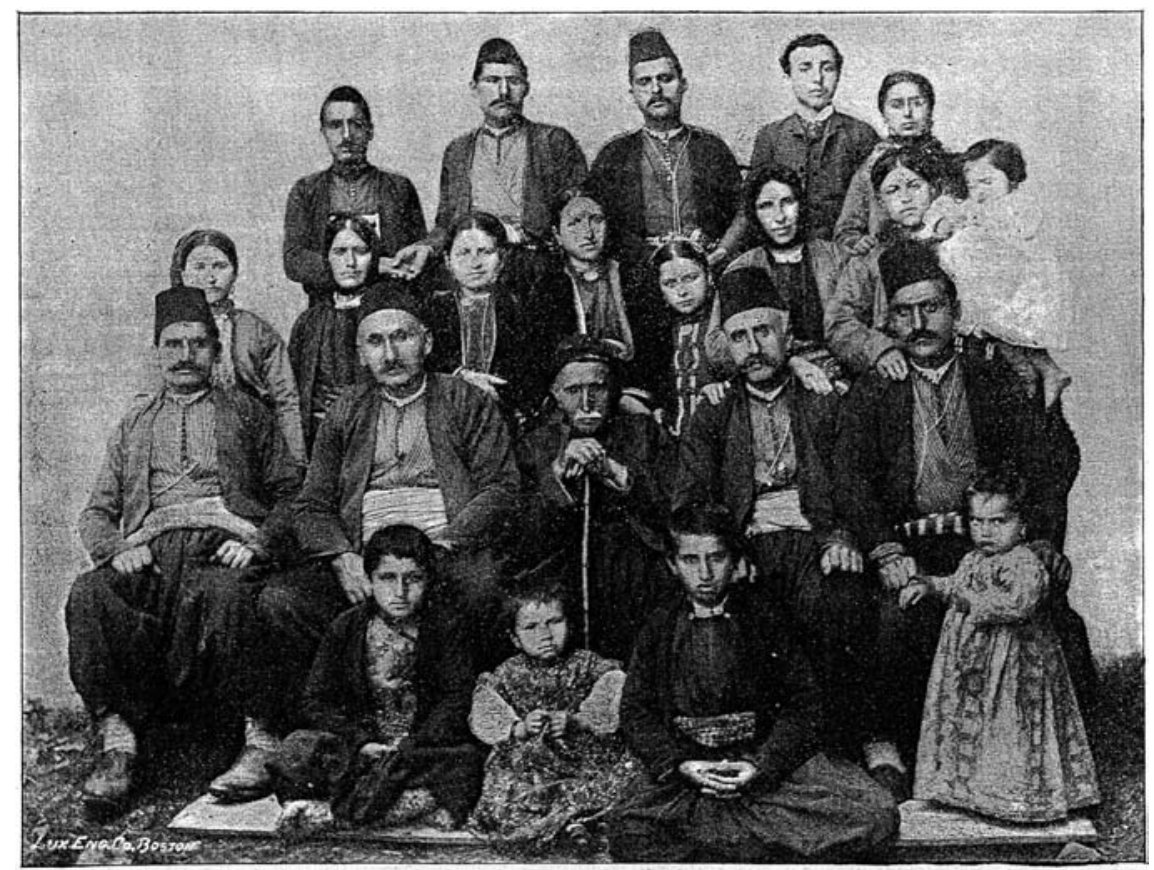

Figure 3.7 An Armenian family. Reproduced from J.E. Pierce, of Bardezag, "For Young People: Who Are the Armenians," Missionary Herald vol. 87 (April 1891): 175-178

an Armenian family that "one of the boys is a graduate of the Bardezag High School. You will have no difficulty in picking him up" (Figure 3.7). ${ }^{51}$

If you could only see the boys as they are when they first come to us, you would understand, at once, what a wonderful change Christian education brings, not only in thought and feeling, but in personal appearance as well. ${ }^{52}$ [Figure 3.8]

The body politics of the ABCFM missionaries also definitely had a gender aspect. They were convinced that the reforming of the family life, the emergence of a true "Christian home", and even the emergence of better phys-

$5^{1} \quad$ J.E. Pierce, of Bardezag, "For Young People: Who are the Armenians," Missionary Herald vol. 87 (April 1891): 175-178. (Italics mine). He is on the upper row, second on the right.

$5^{2}$ Ibid. (Italics mine). 


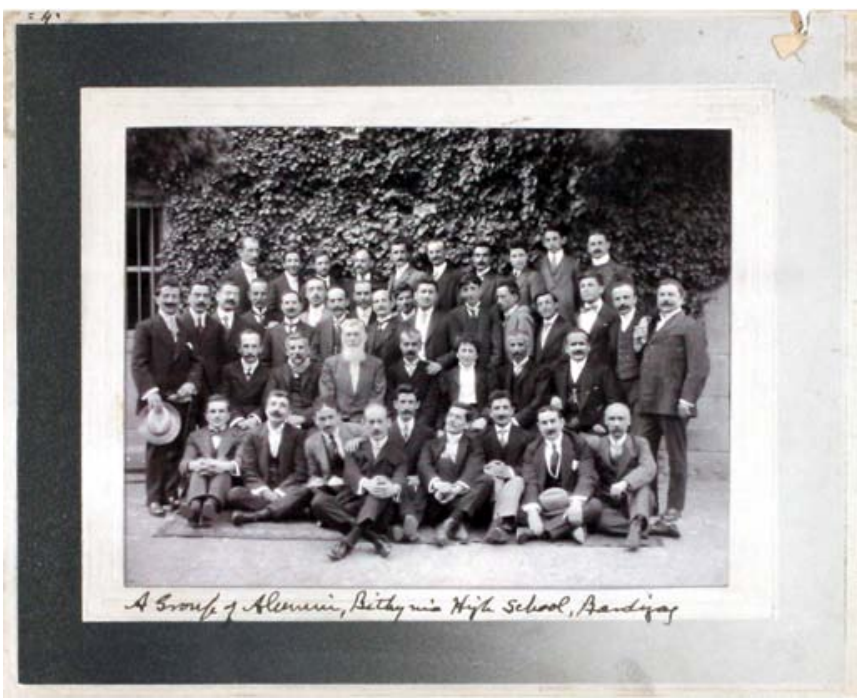

FIGURE 3.8 A group of Alumni, Bithynia High School, Bardizag. SALT Archives, American Board of Commissioners for Foreign Missions / Photographs /Bardizag, ABAHBARDoo9

ical surroundings was absolutely dependent on the missionary influences over women-either in the form of educating, "civilizing", or converting. ${ }^{53}$ The redressing of women's bodies was treated as a visible measure of progress, if not conversion. "Sleeping with day-time clothes", "not making any toilet" in the morning or "not paying attention to their own or their children's dressing or hair" were considered to be serious ills besetting to native women, and thus, should be cured. ${ }^{54}$ Women's authentic dresses and hairstyles often became topics of insult and humiliation. For instance, a certain form of headdress, common among the Greeks of the Black Sea area, was ridiculed because of its resemblance to a toothache covering.

53 Dana Lee Robert, American Women in Mission: A Social History of Their Thought and Practice (Macon: Mercer University Press, 1997); Lisa Joy Pruitt, A Looking-Glass for Ladies: American Protestant Women and the Orient in the Nineteenth Century (Macon: Mercer University Press, 2005); Ellen L. Fleischmann, “'Our Moslem Sisters': Women of Greater Syria in the Eyes of American Protestant Missionary Women," Islam \& Christian Muslim Relations 9 (1998): 307-323; K. Pelin Başç1, "Shadows in the Missionary Garden of Roses: Women of Turkey in American Missionary Texts," in Deconstructing Images of 'The Turkish Woman', ed. Zehra F. Arat (New York: St Martin's Press, 1998), 101-123.

"Influence of American Missionaries on the Social Life of the East." 


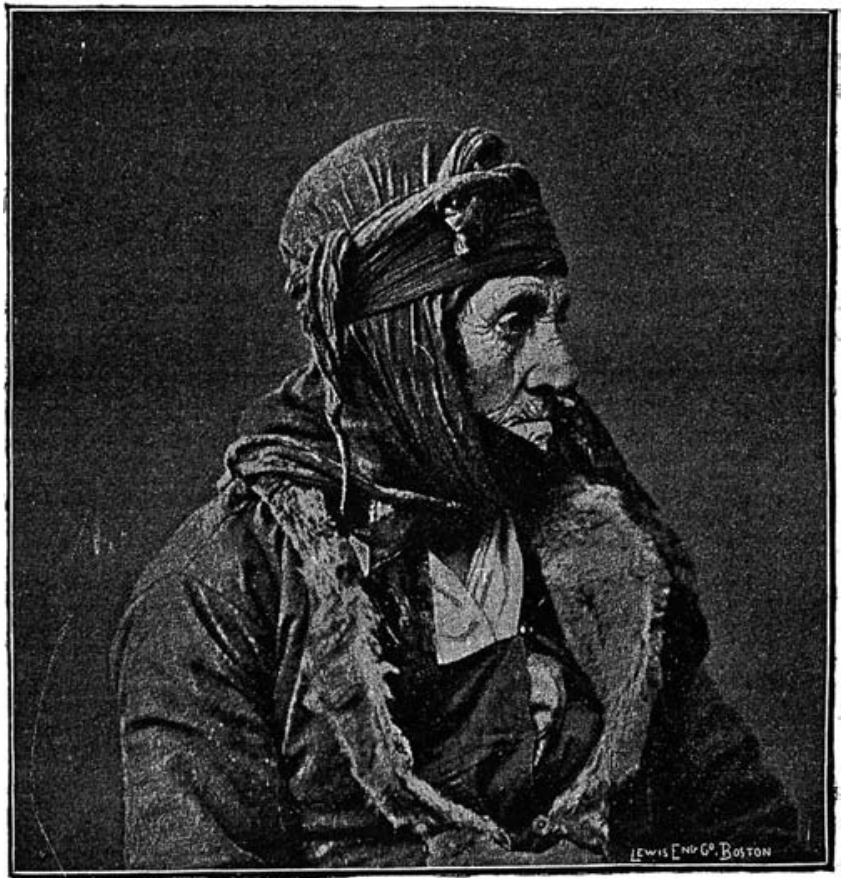

FIGURE 3.9 A Greek peasant woman. Reproduced from Rev. James W. Selye, of Constantinople, "For Young People: A Greek Town in Turkey," Missionary Herald vol. 85 (October 1889): 424-427

You notice the headdress peculiar to the Greek women of that region the arrangement of which impresses you constantly with the fear that they are suffering from chronic neuralgia or toothache. ${ }^{55}$ [Figure 3.9]

Women's conversion necessitated a radical transformation of the style of femininity. The introduction of evangelical Christianity in the communities could supposedly detected by the Western-style clothing and hairstyle that women adopted.$^{56}$ Women's bodies were targeted as a gender-conscious effort to civil-

55 Rev. James W. Selye, of Constantinople, "For Young People: A Greek Town in Turkey," Missionary Herald vol. 85 (October 1889): 424.

56 Inger Marie Okkenhaug, "Gender and Missions in the Middle East," Social Sciences and Missions 23 (2010): 1-6; Barbara Reeves-Ellington, Domestic Frontiers: Gender, Reform, and American Interventions in the Ottoman Balkans and the Near East (Amherst and Boston: University of Massachusetts Press, 2013); Norbert Friedrich, Uwe Kaminsky, and Roland 
ize and reshape them as symbols of domesticity in the home, as well as symbols of evangelical values in public. ${ }^{57}$

In sum, it was expected that the example and instruction of the missionaries in the field had a visible impact on the native communities, such that one could see the difference of those who were in contact with the Protestants. The "word of the Gospel" was supposed to transform not only beliefs but should be projected in the looks.

\section{$4 \quad$ Cure for Souls, Cure for Bodies}

In the second half of the 19th century, the rapprochement of spiritual conversion to bodily improvement found expression in the promotion of natural science. Shin K. Kim calls this form of Protestant Christianity as an "antiseptic religion". By the intermingling of American evangelical Christianity and the concept of hygiene (germ theory), there occurred a discourse of 'medicalized religion'. Most of the physicians within the American missionary corps were influenced by the germ theory of illness and considered Western medicine as an efficient tool to evangelize the country. Washing away sins from the soul became analogous to washing away germs from the body. 58

The ABCFM missionaries regarded the natural sciences, especially medicine, as part of their broader spiritual commitments. Although early medical activity by missionaries was usually a short-term, humanitarian response, medical activity soon encompassed an evangelistic strategy prompted by the sulky progress of conversion. There was an appreciation of the value of medical missionaries, especially in areas where mission's penetration was otherwise extremely difficult or where disease made their activity problematic. A postulate of medical missions was that curing patients gave legitimacy to the American mission-

Loffler, eds., The Social Dimension of Christian Missions in the Middle East: Historical Studies of the 19th and 2oth Centuries (Stuttgart: Franz Steiner Verlag, 2010).

In her work on female missionary schools and physical education in the Ottoman Empire, Kahlenberg makes an analogous analysis. Caroline Kahlenberg, “'The Gospel of Health': American Missionaries and the Transformation of Ottoman/Turkish Women's Bodies, 189o-1932," Gender \& History 28, no. 1 (2016): 152.

$5^{8}$ Shin K. Kim, "An Antiseptic Religion: Discovering A Hybridity on the Flux of Hygiene and Christianity," Journal of Religion and Health 47 (2008): 253-262. 
aries' public work and greatly facilitated preaching. ${ }^{99}$ The ABCFM missionaries quickly discovered the indisputable usefulness of the medical services in breaking down opposition, dissipating prejudice and entering into the "hearts and homes of the high and the low, the rich and the poor".60 They underlined that health-related activities received the highest official recognition in the Ottoman Empire, and thus facilitated the working of all other branches, such as in the realms of education and preaching. Doctors were welcomed as persona grata even in the homes of the officials and state bureaus. Caring for the sick was a remarkable opportunity to spread the Protestant influence and better penetrate into the hosting communities. Therefore, the value of this department of the missions was considered to be exceptional especially at the early stages of establishing a mission station.

The mission stations had greater chances of communicating their religious teachings, when they were able to offer permanent health care facilities, such as infirmaries, hospitals, or asylums. Hospitals, in that respect, promised an open space, the rules of which were under missionary control such that the institution brought about different sorts of interpersonal relations. ${ }^{61}$ Medical missions were founded with the explicitly stated objective of entering into the hearts and minds of the people. In other words, people's bodies were utilized as gates to their beliefs, and betterment of their physical condition was interpreted as a sign of their religious enlightenment.

The advice and personal services of physicians were thought to facilitate the establishment of sanitary measures in hitherto neglected communities. The missionaries' presence equipped the converted Christians with an exceptional immunity during the prevalence of deadly visitations of diseases. The "testimonies" from various mission stations pointing to this "fact" were praised as explicit and material proofs of the gains the converts accrued by leading a Christian life. Dr Gates underlined that Protestants were not only cleaner in their homes and in their mode of living, but also had "less fear of death", saving them from the plague.

In time of cholera it has been noticed that the evangelical communities were to a marked degree free from the plague, so that in the region of Cili-

59 Philippe Bourmaud, "Public Space and Private Spheres: The Foundation of St Luke's Hospital of Nablus by the CMs (1891-19o1)," in New Faith in Ancient Lands: Western Missions in the Middle East in the Nineteenth and Early Twentieth Centuries, ed. Heleen Murre-van den Berg, SCM 32 (Leiden: Brill, 2006), 133-150.

6o Dennis, Christian Missions, 406.

61 Bourmaud, "Public Space and Private Spheres," 133. 
cia a Turkish official said: 'How is it, O ye Protestants; has God spread His tent over you that you are so spared?' I attribute this largely to the greater cleanliness and less fear of death prevailing among evangelical Christians. ${ }^{62}$

It may be truthfully said that the general health of the Protestants as a body has been greatly improved by their superior intelligence in regard to the laws of health, and by the attention which they have given to the sanitary condition of their homes. ${ }^{63}$

Medical work by American missionary physicians was, therefore, associated with the dissemination of Protestantism and the message of conversion. It was not only bodies that received attention in American missionary hospitals and clinics, but the souls as well. In that respect, the cure of souls went hand in hand with the cure of the diseases. ${ }^{64}$ Medical missions offered both a path to salvation and reformation of minds and daily habits. Daniel Bliss, who had joined the Syria mission station in 1855 and who served as the Syrian Protestant College President from 1866 to 1902, argued that healing and training in the medical arts and sciences offer one way to fulfill the promise of conversion: either through assuming the role of Christ in healing the body (and soul) and extracting somatic (and spiritual) evils or by striking at "degraded superstitions". 65

The ABCFM and the "Discourse of Civility"

Missionaries' history of the movement, together with certain histories of the missionary movement, have been particularly vulnerable to the accusation of cultural imperialism. As Makdisi underscored, "the remarkable similarity of

62 Dennis, Christian Missions, 465. (Report of Rev. Dr C.F. Gates of Harpoot). (Italics mine).

63 Dennis, Christian Missions, 465. (Report of Rev. J.K. Greene of Constantinople).

64 For more information on missions and medicine, see Rosemary Fitzgerald, "Clinical Christianity: The Emergence of Medical Work as a Missionary Strategy in Colonial India, 180o1914," in Health, Medicine and Empire: Perspectives on Colonial India, eds. Biswamoy Pati and Mark Harrison (New Delhi: Sangam Books, 2001); C. Peter Williams, "Healing and Evangelism: The Place of Medicine in Late Victorian Protestant Missionary Thinking," in The Church and Healing, ed. W.J. Sheils (Studies in Church Hist., xix, Oxford, 1982); Roy M. MacLeod and Milton James Lewis, eds., Disease, Medicine, and Empire: Perspectives on Western Medicine and the Experience of European Expansion (London: Routledge, 1988).

65 Cited in Elshakry, "The Gospel of Science," 178. 
writing on 'the' heathen and their routine denigration of foreign cultures and their determination to restructure them have made them an obvious target".66 It is apparent that the American Board adopted a resolute Puritan equation of its particular Christianity with civilization and paved the way for the reproduction of the discourse of the stagnant East, with its ignorant, unenlightened, non-White peoples.

Photography played a crucial role in the classification, conceptualization and visualization of "other" peoples. ${ }^{67}$ Even as late as the turn of the century, photographs were still imbued with the unencumbered spirit of the Enlightenment idea of "noble savage". ${ }^{68}$ Therefore, the discourse of educating and reforming the "heathens" by the "messengers of civilization and Christianity" was very strong. Although there were some infrequent tones of curiosity for indigenous forms of life, the American missionaries were more often judgmental in their evaluation of the peoples of the East. Most local customs and traditions were interpreted as evil and degenerate forms of religiosity and the cure was to introduce them to true Christianity.

Photographs usually preferred to exhibit different communal groups and/or tribes, costumes, and trades staged with primitivizing props, as ideas of clearly visible superiority developed by racist aspects of 19th-century evolutionary thinking shaped missionary attitudes towards different communities. ${ }^{69}$ In this respect, ABCFM missionaries' line of thinking was shaped with such "progressivist" tendencies that societies and peoples would eventually (or sometimes with outside intervention) progress from a backward state of existence to modernity, from barbarism to civility. Thus, different religious and linguistic communities in Anatolia were assumed to be at earlier stages of a teleological march toward "civilization". From within this ideological framework, the function and value of the photographs of Orthodox Christians who converted to Protestantism with the preaching of ABCFM missionaries was primarily attached to their meaning as documents of progress as a historical process. $^{70}$ Therefore, photography, within the context of cultural criticism, was

66 Ussama Makdisi, Artillery of Heaven: American Missionaries and the Failed Conversion of the Middle East (Ithaca: Cornell University Press, 2008), 9.

67 Reina Lewis, Rethinking Orientalism: Women, Travel and the Ottoman Harem (New Brunswick, NJ: Rutgers University Press, 2004), 209.

68 Behdad notes that since its very inception, photography was intertwined with Europe's Orientalist vision of the Middle East. Ali Behdad, "The Power-ful Art of Qajar Photography: Orientalism and (Self)-Orientalizing in Nineteenth Century Iran," Iranian Studies 34, nos. 1-4 (2001): 141-151.

69 Erdogdu, "Picturing Alterity," 119.

70 Photography featured as an important tool in furnishing the Orientalist system of know- 
also instrumental for disciplinary purposes: it was a record of the converted subjects. ${ }^{71}$ The images or imagery produced a dynamic rhetoric of cultural and ethnographic difference between evangelical Protestants and non-Christian "peoples" and "places". ${ }^{72}$

The logic behind the usage of visual material was, without a doubt, to illustrate how miracles came true by evangelicalism. Western styles of dress, physical decorum and hygiene were treated as signifiers of Protestant faith, piety, and virtue that native peoples came to embrace. American Board missionaries perceived the various forms of Orthodox Christianity as "nominal Christians", as Christians only in name but not in practice. Through contact with the ABCFM missionaries, "nominal" or "professing" Christians would find not only religious guidance but also move forward along the evolutionary path to "civility". Civilizing "native peoples" was possible by teaching them how to read - to be saved from the ignorance of illiteracy, by furnishing them with a talent - to gain their own honorable livelihood, and by leading them to genuine Christian way - to get rid of nominal/schismatic Christianity in a gradual fashion. ${ }^{73}$

As I argued throughout the article, since the spiritual state of existence was invisible, conversion was practically reduced to retouchings in the material state of existence. The ABCFM missionaries used visual representations, photography and narrative descriptions as evidence of successful proselytization. They referred to bodily and physical conditions as material representations and mirrors of the religious and moral state of people. New forms of clothing, Western-style hairdressing, altered postures and looks, and also the use of the English language - all these were interpreted as signifiers to measure the extent of dissemination of Christian belief among native people. As tan-

ledge with an efficient and empirical way for gathering data. Ali Behdad, "Sevruguin: Orientalist or Orienteur?" in Sevruguin and the Persian Image: Photographs of Iran, 1870-1930, ed. Frederick N. Bohrer (Washington: Smithsonian Institution, 1999), 79-98.

71 Mary Roberts, Intimate Outsiders: The Harem in Ottoman and Orientalist Art and Literature (Durham: Duke University Press, 2007), 176.

72 Sheehi discusses the linkage between the consolidation of a bourgeois identity and photography. Stephen Sheehi, "A Social History of Early Arab Photography or a Prolegomenon to an Archaeology of the Lebanese Imago," IJMES 39 (2007): 177-208.

73 In her work on Scandinavian and German missions in Anatolia (among Armenians), Okkenhaug underlines that the Scandinavian missionaries frequently repeated that they do not want to turn Armenians into "Germans" - meaning Protestants — but to create "living Christians", which might be interpreted as a reformation within the Armenian Church, Inger Marie Okkenhaug, "Women on a Mission! Scandinavian Welfare and the Armenians in the Ottoman Empire, 1905-1917," in Interpreting Welfare and Relief in the Middle East, eds. Nefissa Naguib and Inger Marie Okkenhaug (Leiden: Brill, 2008). 
gible proofs and easily malleable targets, refashioning bodies and places were part of the American missionary agenda in their general aspirations to evangelize. Given the difficulty in providing evidence of conversion, these material and physical transformations were solid outcomes of their efforts and promotable results of missionary work. Metamorphosis from "nominal", so false to true Christianity was merely "a process of self-fashioning modeled by the dictates of the missionaries". ${ }^{74}$

\section{Bibliography}

\section{ABCFM Reports and Publications}

"Influence of American Missionaries on the Social Life of the East." Missionary Herald vol. 69 (June 1873): 187-19o.

"For Young People: The Empire of the Sultan." Missionary Herald vol. 77 (January 1881): 33-39.

Mission Stories of Many Lands: A Book for Young People. Boston: The ABC FM, 1885.

Herrick, Rev. George F. "Canon Taylor on Missionary Methods." Missionary Herald vol. 85 (January 1889).

Selye, Rev. James W. of Constantinople. "For Young People: A Greek Town in Turkey." Missionary Herald vol. 85 (October 1889): 424-427.

Pierce, J.E. of Bardezag. "For Young People: Who are the Armenians." Missionary Herald vol. 87 (April 1891): 175-178.

Reynolds, Rev. George C. "For Young People: A Gospel Triumph in the Land of Ararat.” Missionary Herald vol. 91 (May 1895): 212-216.

"Fifty Thousand Orphans made so by the Turkish Massacres of Armenians." New York Times, December 18, 1896.

"Merzifon Station Report, 1897." ABC 16.9.3, reel 6o6, nos. 698-670.

Nason, Miss. "Work for Orphans." Missionary Herald vol. 93 (March 1897): 112-113.

"Editorial Paragraphs." Missionary Herald vol. 93 (June 1987).

In Lands Afar: A Second Series of Mission Stories of Many Lands, A Bookfor Young People. Boston: ABCFM, 1897.

"Mardin Orphanage, Reports for 1897-1899." ABC 16.5, reel 512, nos. 201-230.

"For Young People: Orphans in Turkey." Missionary Herald vol. 94 (May 1898): 204-208.

"Editorial Paragraphs." Missionary Herald vol. 95 (October 1899).

Dennis, Rev. James S. Christian Missions and Social Progress: A Sociological Study of Foreign Missions. New York: Fleming H. Revell Company, 1899.

74 Williams, Framing the West, 92. 
White, George E. “Annual Report of Merzifon Station 1905-1906." SALt Archives, American Board of Commissioners for Foreign Missions, ABAAS Rooo313, https://archives .saltresearch.org/handle/123456789/46791.

\section{Secondary Literature}

Alloula, Malek. The Colonial Harem. Minneapolis, Minn.: University of Minnesota, 1986.

Anderson, Margaret Lavinia. “'Down in Turkey, Far Away': Human Rights, the Armenian Massacres, and Orientalism in Wilhelmine Germany." The Journal of Modern History 79 (2007): 8o-111.

Badr, Habib. "American Protestant Missionary Beginnings in Beirut and Istanbul: Policy, Politics, Practice and Response." In New Faith in Ancient Lands: Western Missions in the Middle East in the Nineteenth and Early Twentieth Centuries, edited by Heleen Murre-van den Berg, 211-240. SCM 32. Leiden: Brill, 2006.

Başçı, K. Pelin. "Shadows in the Missionary Garden of Roses: Women of Turkey in American Missionary Texts." In Deconstructing Images of 'The Turkish Woman', edited by Zehra F. Arat, 101-123. New York: St Martin's Press, 1998.

Behdad, Ali. "Sevruguin: Orientalist or Orienteur?" In Sevruguin and the Persian Image: Photographs of Iran, 1870-1930, edited by Frederick N. Bohrer, 79-98. Washington: Smithsonian Institution, 1999.

Behdad, Ali. "The Power-ful Art of Qajar Photography: Orientalism and (Self)-Orientalizing in Nineteenth Century Iran." Iranian Studies vol. 34, nos. 1-4 (2001): 141-151.

Bourmaud, Philippe. "Public Space and Private Spheres: The Foundation of St Luke's Hospital of Nablus by the CMs (1891-1901)." In New Faith in Ancient Lands: Western Missions in the Middle East in the Nineteenth and Early Twentieth Centuries, edited by Heleen Murre-van den Berg, 133-150. SCM 32. Leiden: Brill, 2006.

Çizgen, Engin. Photography in the Ottoman Empire. Istanbul: Haşet Kitabevi, 1987.

Deringil, Selim. “'The Armenian Question is Finally Closed': Mass Conversions of Armenians in Anatolia during the Hamidian Massacres of 1895-1897." Comparative Studies in Society and History 51 (2009): 344-371.

Elshakry, Marwa. "The Gospel of Science and American Evangelism in Late Ottoman Beirut." Past and Present 196, no. 1 (2007): 173-214.

Erdogdu, Ayshe. "Picturing Alterity: Representational Strategies in Victorian Type Photographs of Ottoman Men." In Colonialist Photography:Imag(in)ing Race and Place, edited by Eleanor M. Hight and Gary D. Sampson, 1107-1125. London: Routledge, 2004.

Fitzgerald, Rosemary. "Clinical Christianity: The Emergence of Medical Work as a Missionary Strategy in Colonial India, 180o-1914." In Health, Medicine and Empire: Perspectives on Colonial India, edited by Biswamoy Pati and Mark Harrison. New Delhi: Sangam Books, 2001. 
Fleischmann, Ellen L. “'Our Moslem Sisters': Women of Greater Syria in the Eyes of American Protestant Missionary Women." Islam \& Christian Muslim Relations 9 (1998): 307-323.

Fleischmann, Ellen. "Evangelization or Education: American Protestant Missionaries, the American Board, and the Girls and Women of Syria (1830-1910)." In New Faith in Ancient Lands: Western Missions in the Middle East in the Nineteenth and Early Twentieth Centuries, edited by Heleen Murre-van den Berg, 263-28o. sсм 32. Leiden: Brill, 2006.

Fleischmann, Ellen. "Lost in Translation: Home Economics and the Sidon Girls' School of Lebanon, c. 1924-1932." Social Sciences and Mission 23 (2010): 32-62.

Friedrich, Norbert, Uwe Kaminsky, and Roland Loffler, eds. The Social Dimension of Christian Missions in the Middle East: Historical Studies of the 19th and 20 th Centuries. Stuttgart: Franz Steiner Verlag, 2010.

Hight, Eleanor M., and Gary D. Sampson, eds. Colonialist Photography: Imag(in)ing Race and Place. London: Routledge, 2004.

Kahlenberg, Caroline. “'The Gospel of Health': American Missionaries and the Transformation of Ottoman/Turkish Women's Bodies, 189o-1932." Gender \& History 28, no. 1 (2016): 150-176.

Kieser, Hans-Lukas. Derverpasste Friede. Mission, Ethnie und Staat in den Ostprovinzen der Türkei 1839-1938. Zurich: Chronos Verlag, 2000.

Kieser, Hans-Lukas. "Mission as Factor of Change in Turkey (Nineteenth to First Half of Twentieth century)." Islam and Christian-Muslim Relations 13 (2002): 391-410.

Kim, Shin K. "An Antiseptic Religion: Discovering A Hybridity on the Flux of Hygiene and Christianity." Journal of Religion and Health 47 (2008): 253-262.

Lalvani, Suren. Photography, Vision, and the Production of Modern Bodies. Albany, N.Y.: State University of New York Press, 1996.

Landau, Jacob M. Exploring Ottoman and Turkish History. London: Hurst \& Co., 2004.

Lawson, Barbara. "Collecting Cultures: Canadian Missionaries, Pacific Islanders, and Museums." In Canadian Missionaries, Indigenous Peoples: Representing Religion at Home and Abroad, edited by Alvyn Austin and Jamie S. Scott, 235-261. Toronto: University of Toronto Press, 2005.

Lemke, Wolf-Deiter. "Ottoman Photography: Recording and Contributing to Modernity." In The Empire in the City: Arab Provincial Capitals in the Late Ottoman Empire, edited by Jens Hanssen, Thomas Philipp, and Stefan Weber. Beirut: Ergon Verlag Würzburg, 2002.

Lewis, Reina. Rethinking Orientalism: Women, Travel and the Ottoman Harem. New Brunswick, NJ: Rutgers University Press, 2004.

Löffler, Roland. "The Metamorphosis of a Pietistic Missionary and Educational Institution into a Social Services Enterprise: The Case of the Syrian Orphanage (186o1945)." In New Faith in Ancient Lands: Western Missions in the Middle East in the 
Nineteenth and Early Twentieth Centuries, edited by Heleen Murre-van den Berg, 151174. SCM 32. Leiden: Brill, 2006.

MacLeod, Roy M., and Milton James Lewis, eds. Disease, Medicine, and Empire: Perspectives on Western Medicine and the Experience of European Expansion. London: Routledge, 1988.

Makdisi, Ussama. The Culture of Sectarianism: Community, History, and Violence in Nineteenth-Century Ottoman Lebanon. Berkeley: University of California Press, 2000.

Makdisi, Ussama. Artillery of Heaven: American Missionaries and the Failed Conversion of the Middle East. Ithaca: Cornell University Press, 2008.

Maksudyan, Nazan. "'Being Saved to Serve': Armenian Orphans of 1894-96 and Interested Relief in Missionary Orphanages." Turcica 42 (2010): 47-88.

Merguerian, Barbara J. "Saving Souls or Cultivating Minds? Missionary Crosby H. Wheeler in Kharpert, Turkey." Journal of the Society for Armenian Studies 6 (19921993):33-6o.

Merguerian, Barbara J. “'Missions in Eden': Shaping an Educational and Social Program for the Armenians in Eastern Turkey (1855-1895)." In New Faith in Ancient Lands: Western Missions in the Middle East in the Nineteenth and Early Twentieth Centuries, edited by Heleen Murre-van den Berg, 241-262. Sсм 32. Leiden: Brill, 2006.

Okkenhaug, Inger Marie. "Women on a Mission! Scandinavian Welfare and the Armenians in the Ottoman Empire, 1905-1917." In Interpreting Welfare and Relief in the Middle East, edited by N. Naguib and Inger Marie Okkenhaug. Leiden: Brill, 2008.

Okkenhaug, Inger Marie. "Gender and Missions in the Middle East." Social Sciences and Missions 23 (2010): 1-6.

Prochaska, David. “Archive of l'Algerie Imaginaire." History and Anthropology 4 (1990): 373-420.

Pruitt, Lisa Joy. A Looking-Glass for Ladies: American Protestant Women and the Orient in the Nineteenth Century. Macon: Mercer University Press, 2005.

Reeves-Ellington, Barbara. Domestic Frontiers: Gender, Reform, and American Interventions in the Ottoman Balkans and the Near East. Amherst and Boston: University of Massachusetts Press, 2013.

Robert, Dana Lee. American Women in Mission: A Social History of Their Thought and Practice. Macon: Mercer University Press, 1997.

Roberts, Mary. Intimate Outsiders: The Harem in Ottoman and Orientalist Art and Literature. Durham: Duke University Press, 2007.

Sheehi, Stephen. "A Social History of Early Arab Photography or a Prolegomenon to an Archaeology of the Lebanese Imago." IJMES 39 (2007): 177-208.

Veer, Peter van der, ed. Conversion to Modernities: The Globalization of Christianity. New York: Routledge, 1996.

Williams, C. Peter. "Healing and Evangelism: The Place of Medicine in Late Victorian 
Protestant Missionary Thinking." In The Church and Healing, edited by W.J. Sheils. Studies in Church History 19. Oxford, 1982.

Williams, Carol. Framing the West: Race, Gender, and the Photographic Frontier in the Pacific Northwest. Oxford: Oxford University Press, 2003. 